\title{
CONSTITUTIONAL CHARACTERISTICS OF PHYSICAL DEVELOPMENT IN THE KYRGYZ POPULATION
}

\author{
Kyialbek Sh. Sakibaev ${ }^{1 *}$, Dmitry B. Nikityuk ${ }^{2,3}$, Aiperi A. Alimbekova ${ }^{1}$, Nurbek M. \\ Mamashov $^{4}$, Ravshanbek M. Dzhumaev ${ }^{5}$, and Gulay T. Dzholdosheva ${ }^{6}$ \\ ${ }^{1}$ Department of Anatomy, Histology and Normal Physiology, International Medical Faculty, Osh \\ State University, Kyrgyz Republic \\ ${ }^{2}$ Laboratory of Sports Anthropology and Nutrition, Federal Research Centre of Biotechnology and \\ Food Safety, Moscow, Russian Federation \\ ${ }^{3}$ Department of Operative Surgery and Topographical Anatomy, Moscow State Medical University \\ Named after I.M. Sechenov, Moscow, Russian Federation \\ ${ }^{4}$ Department of Oncology, Ophthalmology and Otorhinolaryngology, Medical Faculty, Osh State \\ University, Osh, Kyrgyz Republic \\ ${ }^{5}$ Cycle of General medical disciplines, Medical College, Osh Kyrgyz-Uzbek University, Osh, Kyrgyz \\ Republic \\ ${ }^{6}$ Department of Histology and Pathologic Anatomy, Medical Faculty, Osh State University, Osh, \\ Kyrgyz Republic
}

\begin{abstract}
Personalized medicine is one of the priorities of the development of modern medical science. The aim of this study was to identify somatotypological features of physical development in men and women of the Kyrgyz population. The physical status of 1083 men and women in the Kyrgyz population (Osh, Kyrgyzstan) was studied by the method of complex anthropometry and somatotyping. The whole complex of the conducted anatomical and anthropometric examinations corresponded to generally accepted ethical standards, with the registration of informed consent from all the examined persons. The statistical analysis included the calculation of the arithmetic mean of the indicators of their mistakes. The differences were evaluated using the Student's method at $\mathrm{p}<0.05$. The results show that among women of youth and mature age, representatives of hypersthenic and normosthenic body types predominate; women of asthenic type are a minority (classification of $\mathrm{M}$. V. Chernorutsky). Women of indeterminate somatotype (scheme of I. B. Galant et al.) belong either to the normal or hypersthenic type and never to the asthenic type. In men, the abdominal somatotype corresponds to a hypersthenic, thoracic-asthenic physique; men of the muscular type-mainly normosthenics; men of indeterminate type are both hypersthenics and normosthenics. The obtained data, undoubtedly, have not only theoretical, but also significant practical significance.
\end{abstract}

* Corresponding author: sakibaev@oshsu.kg 


\section{Relevance}

Personalized medicine, based on an individual approach to patients, is one of the priorities of the development of modern medical science. A personal approach to the implementation of measures of prevention, diagnosis, treatment, and rehabilitation of an individual is based on taking into account the specific features of the body, the specifics of its reactivity, the peculiarity of the metabolome, nutriome, molecular-genetic and other characteristics of the patient $[1,2]$.

The basic method for assessing physical development, nutritional status, and determining the level of health in this approach should obviously be the method of constitutional analysis (somatotyping) [3,4], which allows the analysis of the population to identify an individual belonging to different somatotypes $[5,6]$.

Taking into account the temporal (epochal) variability of body features and indicators of physical development, the presence of acceleration, retardation of development and some other phenomena $[7,8,9]$, data on the physical status of the population should be constantly reviewed and supplemented. The need to implement this approach is constantly pointed out in the scientific literature $[10,11,12]$. Despite a significant number of works of this profile $[13,14,15]$, the physical status of different population groups is not uniformly reflected; many of the data are not representative, the studies were performed in people who differ significantly in age and gender; the results of many anatomical and anthropometric studies are outdated. It should also be noted that in the scientific literature there are virtually no anthropometrically directed studies that characterize both female and male populations at the same time (the authors consider either the first or the second, but very rarely both of them at the same time). This creates conditions for the formation of a kind of "gender imbalance", since such simultaneous studies performed by one specialist in relation to women and men are especially important, given the uniformity of approaches, methodological uniformity, which is significant in anthropometric studies $[16,17,18,19]$.

The constitutional predisposition of a person to the development of many somatic diseases, as well as the disparity in the effectiveness of their treatment and rehabilitation in representatives of different constitutional types has also been established [20, 21, 22]. Therefore, the method of somatotypological (constitutional-anatomical) analysis deserves implementation in terms of practical applications for clinical practice.

The aim of this study was to identify somatotypological features of physical development in men and women of the Kyrgyz population.

\section{Research materials and methods}

Anthropometric and bioimpedance methods were used to assess the physical development of 1983 men and women of young and mature age, ethnic Kyrgyz living in Osh and its environs. Among them, we analyzed anatomical and anthropometric indicators in 1028 women of different age groups - youth (16-20 years, 310 girls, group 1), mature age (period 1, 21-35 years, 308 women, group 2; period 2, 36-55 years, 410 women, group 3). In the male part of the actual sample ( 955 cases), 355 young men (17-21 years, group 1$)$ and mature men (period 1, 22-35 years, 300 observations, group 2; period 2, 36-60 years, 300 men, group 3) were examined. In the female sample at the time of the survey, the average age was $18.5+2.2$ years in group $1,29.6+2.5$ years in group 2, and $44.6+1.5$ years in group 3. Among the examined men, the average age of the representatives of the $1 \mathrm{st}$ group was $19.3+1.8$ years, in the 2 nd group $-27.5+2.2$ years, in the 3rd group- $47.8+2.2$ years.

We used the generally accepted traditional scheme of age periodization of ontogenesis, approved at the VII All-Union Conference on the Problems of Age morphology, 
Physiology and Biochemistry of the APN of the USSR (Moscow, 1965). The bioimpedance analyzer ABC-01 "Medass" (LLC STC "MEDASS", Russia) was used for bioimpedance measurement. The entire set of anatomical and anthropometric examinations performed was in accordance with generally accepted ethical standards (the decision of the local ethics committee of Osh State University), with the informed consent of all the examined persons. The sampling was based on the principle of voluntary participation.

Somatotyping - (selection of constitutional types, somatotypes) was performed separately for women and men. For somatotyping of women, we used the traditional scheme of constitutional diagnostics of I. B. Galant - V. P. Chtetsov - B. A. Nikityuk (1983), which was recognized as the most adequate (Petukhov A. B. et al., 2015). Three constitutional groups (categories) were distinguished, within which seven somatotypes were differentiated. The leptosomal constitution combined the asthenic and stenoplastic types; the mesosomal constitution combined the picnic and mesoplastic types.; megalosomal constitution - athletic, sub-athletic, and euriplastic somatotypes. In men, somatotyping was performed on the basis of indicators, including physiometric (dynamometry $(\mathrm{kg})$ of the right and left hands. Possible combinations of the development scores of the main body components for men are presented in Table 8 (Nikityuk B. A., Chitetsov V. P., 1993; Tutelyan V. A. et al., 2017). The rationale for choosing this scheme was that it is recommended for the age group we are studying-for men 17-55 years old (V. P. Chytetsov, 1078). The result of somatotyping was the selection of representatives of the thoracic, muscular, abdominal and indeterminate somatotypes. In accordance with the recommendations of V. P. Chtetsov (1978) and V. N. Nikolenko et al. (2017), the selection of transitional somatotypes (musculoskeletal, thoracic-muscular, etc.) was not carried out taking into account their lack of objectivity, informativeness and lack of clear differentiating criteria. Taking into account the insufficient prevalence of these schemes (Galanta I. B. et al. (1983), Nikityuk B. A., Chtetsov V. P., 1983) somatotyping in the clinic we also classified representatives of the population in accordance with the classification adopted in practical medicine by M. V. Chernorutsky (1925). In this respect, normosthenics, asthenics and hypersthenics were distinguished (Parfenova I. A., 2007, etc.). For somatotyping, the definition of the somatic development index (Pinier index) was used, which was calculated by the formula: $\mathrm{IP}=\mathrm{L}-(\mathrm{P}+\mathrm{T})$, where $\mathrm{L}$ is body length $(\mathrm{cm}) ; \mathrm{P}$ is body weight $(\mathrm{kg})$; $\mathrm{T}$ is chest circumference.

Statistical processing of the results was performed on a personal computer using Microsoft Excel statistical programs and the STATISTICA package (v. 6.0). The results of the study are presented as arithmetic averages (X), with the error of representativeness (Sx), fixed the minimum (Min) and maximum (Max) of individual variants of each parameter. To assess the significance of the differences between the indicators, the Student's criterion was used; the differences between the two compared values were considered significant at $\mathrm{p}$ $<0.05$.

\section{Results of the study}

On the basis of anthropometry, data were obtained (see the following tabular materials) that allow us to distribute the studied female population in accordance with the belonging of individuals to a specific constitutional group. In particular, the following was shown (Table 1). 
Table 1. Distribution by constitutional groups of women of youth and mature age (abs. in \%).

\begin{tabular}{|c|c|c|}
\hline \multirow{2}{*}{ Constitutional group } & \multicolumn{2}{|c|}{ Indicator value } \\
\cline { 2 - 3 } & Absolut numbers & in \%. min-max \\
\hline leptosomal & 208 & $20 \pm 3.2$ \\
& & $14-25$ \\
\hline mesosomal & 330 & $32 \pm 0.1$ \\
& & $29-35$ \\
\hline megalosomal & 346 & $33 \pm 0.1$ \\
& 144 & $15 \pm 0.1$ \\
\hline Indeterminate & & $12-18$ \\
\hline
\end{tabular}

Note: when evaluating the relative values of the occurrence of a trait, its values in youth and adulthood (the extreme values of the indicators) were taken as the minimum and maximum.

According to the presented data, women of the leptosomal constitutional group were identified in 208 cases, the mesosomal group- in 330, the megalosomal group - in 346, and the undetermined group - in 144 cases (see Table 9). The percentage representation in the population showed that the content of women of the leptosomal constitutional group $(20 \%)$ is 1.6 times less than the mesosomal group $(\mathrm{p}<0.05)$, the megalosomal group -1.7 times $(\mathrm{p}$ $<0.05)$, but more than the representatives of the undetermined group -1.4 times $(p<0.05)$. At the same time, the individual minimum and maximum percentage of women of different constitutional groups with leptosomy is less than for the meso - and megalosomal groups, but more than for the indefinite constitutional group.

The analysis of the representation of women of different constitutional groups in the youth, 1st and 2nd periods of adulthood showed the following (Table 2).

Table 2. The distribution of women by constitutional groups, taking into account age (abs. in\%).

\begin{tabular}{|c|c|c|c|c|c|}
\hline Age & Number of & \multicolumn{4}{|c|}{ Constitutional group } \\
\cline { 3 - 6 } & researches & leptosomal & mesosomal & megalosomal & Indeterminate \\
\hline young & 310 & $76(24 \%)$ & $100(32 \%)$ & $92(29 \%)$ & $42(15 \%)$ \\
\hline 1-st adulthood & 308 & $70(22 \%)$ & $102(33 \%)$ & $98(31 \%)$ & $38(14 \%)$ \\
\hline 2-nd adulthood & 410 & $62(15 \%)$ & $128(31 \%)$ & $156(38 \%)$ & $64(16 \%)$ \\
\hline
\end{tabular}

According to the absolute values of the considered trait, the mesosomal constitutional group dominates in adolescence (100 observations), the megalosomal group - 92, the leptosomal group - 76, and the indeterminate constitutional group-42. Among women of the 1st period of mature age, the maximum number was found in mesosomy (102); megalosomal group - 98; leptosomal group - 70 and indeterminate group - 38 cases. Among women of the 2 nd period of mature age, the largest representation was observed in the megalosomal group (156 observations), 128 women belong to the mesosomal group, and approximately the same number of women belong to the leptosomal and indeterminate groups (62 and 64).

Age-specific features of the representation of different constitutional groups in women consist in the fact that among girls (i.e., in adolescence) there is a tendency to the predominance of the proportion of mesosomal and megalosomal groups, over the representation of leptosomal and indefinite constitutional groups. In the 1 st period of adulthood, the relative number of women in the mesosomal and megalosomal groups is greater than in the leptosomal and indeterminate groups. Among women of the 2 nd period of mature age, a tendency to a greater representation of carriers of the megalosomal constitutional group was revealed, compared with the mesosomal group, and, especially, with the leptosomal and indefinite constitutional groups (Table 2). 
We compared the percentage of representatives of each constitutional group in the age aspect and revealed a trend according to which, in comparison with girls, the leptosomal group in the 1 st period of maturity is detected 1.1 times less often, and in the 2 nd period of adulthood-1.6 times less often. The representation of the mesosomal group, compared with girls in the 1st period of adulthood, was 1.03 times more frequent, in the elderly-1.04 times less frequent. The percentage of women of the megalosomal constitutional group, compared with girls, in the 1 st period of adulthood is 1.1 times higher, and in the 2 nd period of adulthood-1.3 times. The relative number of women of an indeterminate group, in comparison with girls, in the 1 st period of mature age is 1.1 times less, and in the 2 nd period of this age-1.2 times more.

Based on somatotyping based on a set of anthropometric and physiometric indicators, we analyzed the representation of different somatotypes in both absolute and relative values in the Kyrgyz population of young and mature men (Table 3).

Table 3. Distribution of the male population by somatotype, taking into account age (abs. in \%).

\begin{tabular}{|c|c|c|c|c|}
\hline \multirow{2}{*}{ Age } & \multicolumn{4}{|c|}{ Somatotypes } \\
\cline { 2 - 5 } & Abdominal & Thoracic & Muscular & Indeterminate \\
\hline Young & $128(36.0 \%)$ & $32(9.0 \%)$ & $88(24.7 \%)$ & $107(30.3 \%)$ \\
\hline 1-st adulthood & $107(35.3 \%)$ & $28(9.55 \%)$ & $81(27.0 \%)$ & $84(28.4 \%)$ \\
\hline 2-nd adulthood & $110(36.6 \%)$ & $33(11.0 \%)$ & $75(25.0 \%)$ & $82(27.4 \%)$ \\
\hline
\end{tabular}

Regardless of age, the abdominal somatotype is dominant in the studied population, and the thoracic somatotype is represented in the smallest number. In adolescence, the absolute number of men of the abdominal somatotype is 4.0 times more than that of the thorac somatotype, 1.5 times more than that of the muscular somatotype, and 1.2 times more than that of the indeterminate somatotype. In the 1 st period of adulthood, the absolute number of men of the abdominal somatotype is 3.8 times more than that of the thoracic somatotype, 1.3 times more than that of the muscular somatotype, and 1.3 times more than the indeterminate somatotype. In the 2 nd period of mature age, the absolute number of men of the abdominal somatotype is 3.3 times greater than that of the thoracic somatotype, 1.5 times more than that of the muscular somatotype, and 1.3 times more than that of the indeterminate somatotype. In percentage terms, in adolescence, the number of men of the abdominal somatotype is 4.0 times greater than that of the thoracic somatotype, 1.5 times more than that of the muscular somatotype, and 1.2 times more than that of the indeterminate somatotype. In the 1 st period of adulthood, the absolute number of men of the abdominal somatotype is 3.8 times more than the thoracic somatotype, 1.3 times more than the muscular somatotype, and 1.3 times more than the indeterminate somatotype. In the 2 nd period of mature age, the absolute number of men of the abdominal somatotype is 3.3 times more than the thoracic somatotype, 1.5 times more than the muscular somatotype, and 1.3 times more than the undefined somatotype.

When analyzing the distribution of the studied male population according to the scheme of M. V. Chernorutsky, we showed that men of the abdominal type belong to hypersthenics, thoracic - to asthenics, and muscular-mainly $(88.5 \%)$ - to normosthenics. Men of indeterminate somatotype, regardless of age, belong to the hypersthenic $(62.4 \%)$ and normosthenic (35.8\%) types.

For the first time, when studying the Kyrgyz population, we showed that mesosomal (31-33\%) and megalosomal (30-38\%) constitutions predominate among young and mature women, while the proportion of leptosomal (15-25\%) and indeterminate (12-16\%) constitutions is significantly lower. The structure of the leptosomal constitution is dominated by stenoplastic (66-77\%) and asthenic thin-boned (18-24\%) and broad-boned (5$10 \%)$ somatotypes are rare. Among mesosomal constitutions, the proportion of mesoplastic $(31-66 \%)$ is greater than that of picnic (34-69\%) somatotype. In the structure of 
megalosomal constitutions, euriplastic tall (22-35\%) and short (58-59\%) somatotypes predominate; subatletic (5-16\%) and especially athletic (0.8-4.4\%) somatotypes are less typical. Close data on the somatotypological analysis of women of the Slavic ethnic group of mature and elderly ages, residents of St. Petersburg, are given by D. A. Starchik (2017). Based on the materials of I. S. Aristova and V. N. According to the results of the study of women in the Saratov region, a large proportion of them are representatives of subatletic $(54.1 \%)$ and stenoplastic (14.9\%) somatotypes. Women of the picnical type were identified in $4.1 \%$, athletic - in $3.4 \%$ and asthenic-extremely rarely $(0.7 \%)$. The authors did not differentiate between mesoplastic and euriplastic constitutional types (although there could not be no women of these somatotypes in the population). Probably, some differences with our data may be due to the presence of regional specifics of the "constitutional diversity" of the population (Nikityuk B. A., Chytetsov V. P., 1983), as well as age-related modifications of the somatotypological status, since the authors studied mainly the physical status of girls.

According to our data, abdominal (35-37\%), muscular (25-27\%), and indeterminate somatotypes (27-30\%) predominate in men of adolescent and mature age, and the thoracic somatotype (9-11\%) is rare. Similar data are given by V. N. Nikolenko et al. (2017) when analyzing the somatotypological belonging of men of youthful and mature age in the city of Saratov and V. A. Tutelyan et al. (2017), analyzing the somatotypological distribution in the residents of Moscow and adjacent regions. It is believed (Nikityuk B. A., Chitetsov V. P., 1983) that the asthenic somatotype is a marker of the slowness of the growth processes of the body (their "stretching" in time), the hypersthenic (picnical) somatotype corresponds to the accelerated and active processes of growth and differentiation of organs and tissues, early puberty. At the same time, these authors admit that the asthenoidness of the somatotype does not always sufficiently reliably reveal the slowness and prolongation of growth processes that are inherently predetermined throughout ontogenesis. It is believed that the increase in body length (height) with asthenic somatotype in women (with thoracic and indeterminate somatotypes in men) significantly slows down and even ends at the age of 21 , and with picnicity (hypersthenic, digestive, brachymorphic physique), athletic and subatletic somatotypes 3-4 years earlier (Nikityuk B. A., Chitetsov V. P., 1983).

In men in adolescence, the proportion of representatives of the abdominal somatotype is $36.0 \%$, the muscular- $34.7 \%$. In the 2 nd period of adulthood, these indicators do not change. The percentage of men of the thoracic somatotype increases from $9.0 \%$ in the adolescent to $11.0 \%$ in the 2 nd period of adulthood, and the undetermined changes from $30.3 \%$ in young men to $27.4 \%$ in the 2 nd period of adulthood (these changes are not reliable). It is believed (Nikityuk B. A., Chytetsov V. P., 1983)that individual changes in the somatotype in ontogenesis can occur, but these processes are not cardinal, but modification. At the same time, the decrease in the proportion of women with an athletic and an increase in the picnical physique with age seems quite logical.

\section{Conclusion}

For the first time in the Kyrgyz population, we compared the constitutional distribution according to the schemes adopted in modern anthropology by M. V. Chernorutsky and I. B. Galant - B. A. Nikityuk - V. P. Chtetsov. It was shown that among women of youth and mature age, representatives of hypersthenic (52\%) and normosthenic (20\%) body types predominate; women of asthenic type are a minority (classification of M. V. Chernorutsky). Women of indeterminate somatotype (scheme I. B. Galanta et al.) belong either to the normal or hypersthenic type (52 and $48 \%$, respectively) and never to the asthenic type. In men, the abdominal somatotype corresponds to a hypersthenic, thoracic-asthenic physique; men of the muscular type-mainly $(85.5 \%)$ - normosthenics; men of indeterminate type are both hypersthenics $(62 \%)$ and normosthenics $(37 \%)$. These data are particularly significant 
in terms of the convergence of positions between anthropology (where the detailed scheme of I. B. Galant - B. A. Nikityuk - V. P. is widespread). V. V. Bunak - B. A. Nikityuk - V. P. Chitetsov-for men) and practical medicine, which uses a simpler scheme for the use of I. B. Galant.

The presented normative anthropometric indicators, the revealed limits of their age, individual, gender and constitutional fluctuations, can serve as a basis for the development of standards of physical development, the formation of various programs for optimizing health, programs for the prevention of its violations.

\section{References}

1. Nikityuk D. B. Anthroponutritiology: development of the ideas of the founders of a new scientific direction. Nutrition issues. 2020. Vol. 89, no. 4. PP. 82-88. DAY: https://doi.org/10.24411/0042-8833-2020-10044

2. Petukhov A. B., Nikityuk D. B., Sergeev V. N. Medical anthropology: analysis and prospects of development in clinical practice. Moscow: Medpraktika, 2015. $511 \mathrm{p}$.

3. Nikitiuk DB, Nikolenko VN, Khairullin RM, Minnibaev ST, Chava SV, Alexeeva NT. The anthropometric method and clinical medicine. Journal of Anatomy and Histopathology 2013; 2(2): 10-14. Russian. https://elibrary.ru/item.asp?id=21028051.

4. Bunak VV. Anthropometry. Moscow, Russia, 1941; 368 p. Russian.

5. Martirosov EG, Nikolaev DV, Rudnev SG. Technologies and methods of determining the composition of the human body. Moscow: Nauka, 2006; 247 p. Russian.

6. Galant IV. New scheme of constitutional types of women. Kazan Medical Journal 1927; (7): 23-34. Russian.

7. Anisimova A.V., Godina E.Z., Nikolaev D.V., Rudnev S.G. Evaluation of the HeathCarter somatotype revisited: new bioimpedance equations for children and adolescents. IFMBE Proceedings. (Eds. F. Simini, P. Bertemes-Filho). Singapore-Heidelberg: Springer. 2016. V. 54. P. 80-83.

8. Toichuev R.M., Zhilova L.V., Paizildaev T.R., Khametova M.S., Rakhmatillaev A., Sakibaev K.S., Madykova Z.A., Toichueva A.U., Schlumpf M., Lichtensteiger W., Weber R. Organochlorine pesticides in placenta in Kyrgyzstan and the effect on pregnancy, childbirth, and newborn health. Environmental Science and Pollution Research. 2018. V. 25. № 32. p. 31885-31894.

9. Muzurova LV, Kochelaevskaya IE. Individual variability of morphometric parameters feet of girls 18-19 years from Saratov region of the Russian Federation. Russian Open Medical Journal 2017; 6: e0104.

10. Pereira D., Severo M., Ramos E., Lucas R., Barros H., Branco J., Santos R.A., Costa L. Potential role of age, sex, body mass index and pain to identify patients with knee osteoarthritis. International Journal of Rheumatic Disease. 2017. vol. 20. no. 2. P. 190198. DOI: 10.1111/1756-185X.12611.

11. Rao W., Su Y., Yang G., Ma Y., Liu R., Zhang S., Wang S., Fu Y., Kou C., Yu Y., Yu Q. Cross-sectional association between body mass index and hyperlipidemia among adults in northeastern China. International Journal of Environmental Research and Public Health. 2016. vol. 13. no. 5. P. 516-524. DOI: 10.3390/ijerph13050516.

12. Arzhakova L.I., Garmaeva D.K., Kononova I.V., Nikitjuk D.B., Nikolaev D.V., Markova I.A., Uarova M.U., Degtyareva T.G., Garmaev T.K. Anthropo-physiometric features and analysis of the body composition of yakut youth of early and late puberty 
in the republic of Sakha (yakutia). International Journal of Biomedicine. 2019. V. 9. № 3. p. 228-232.

13. Ali Abbas S., Seitova A. S., Kadyrbayev Z. M., Kenzhebaev B. K., Sakibaev K. Sh., Belov G. V. Bioimpedance analysis of body composition and anthropometric characteristics of students from India // Medicine of Kyrgyzstan. 2017. Vol. 1. Issue 1. pp. 52-56.

14. Sakibaev K.S., Tashmatova N.M., Nikityuk D.B., Alekseyeva N.T., Klochkova S.V. Characteristics of muscle mass in women of different constitutions. Research Journal of Pharmacy and Technology. 2019. V. 12. № 12. p. 6193-6197.

15. Pinelli C, Garcia PN, Soares DD, Quirino LC, Campos JA. Reproducibility of static antropometric measurments of undergraduate dental students in dental schools. Pesquisa Brasilleria em Odontopediatria e Clinica Intergrada 2011; 11(1): 21-27. Portugues. http://dx.doi.org/10.4034/pboci.v11i1.1250.

16. Petukhov AB, Maev IV, Deryabin VE. Anthropometry: the modern statistical analysis and significance for internal medicine and nutrition. Voprosy Pitaniya 2012; 81(3): 8291. Russian. https://elibrary.ru/item.asp?id=17909155.

17. Nikityuk BA, Chtetsov VP. Morphology of the person. Moscow: Moscow University, 1983; 320 p. Russian.

18. Kliorin AI, Chtetsov VP. Biological problems of the doctrine of the human Constitution. Moscow: Nauka, 1979: 349 p. Russian.

19. Kyialbek Sh. Sakibaev, Dmitry B. Nikityuk, Ibragim N. Atabaev, Absamat E. Sattarov and Mirlan K. Nuruev. Somatotypological features of the physique of ethnic kyrgyz women of different ages. ASIA LIFE SCIENCES: The Asian International Journal of Life Sciences, Supplement 22(2): 185-199, 2020.

20. Tutelian VA, Razumov AN, Klochkova SV, Alexeeva NT, Rozhkova EA, Kvaratskhelia AG, Nikitiuk DB. Features of macro-anthropometric parameters in women of different somatotypes. Morphological Newsletter 2017; (1): 20-22. Russian. https://elibrary.ru/item.asp?id=29064033.

21. Kukes VG, Nikolenko VN, Pavlov CS, Zharikova TS, Marinin VF, Gridin LA. The correlation of somatotype of person with the development and course of various diseases: results of Russian research. Russian Open Medical Journal 2018; 7: e0301.

22. Fursov AB, Fursov RA. Correlation of anthropometric parameters in patients with metabolic syndrome before endoscopic gastro-bypass surgery. European Journal of Natural History 2016; (1): 5-6. https://elibrary.ru/item.asp?id=26017658. 